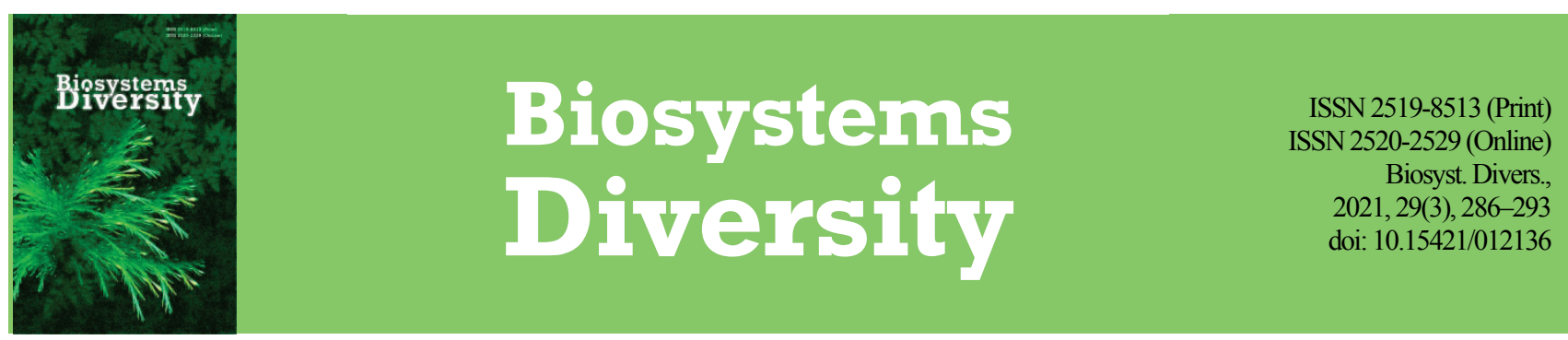

\title{
Breeding of black-winged stilt Himantopus himantopus in muddy sites of a wastewater treatment plant
}

\author{
Y. P. Mamedova, A. B. Chaplygina \\ H. S. Skovoroda Kharkiv National Pedagogical University, Kharkiv, Ukraine
}

Article info

Received 11.08.2021 Received in revised form 03.09 .2021 Accepted 04.09.2021

H. S. Skovoroda Kharkiv National Pedagogical University, Alchersky st., 29, Kharkiv, 61002, Ukraine. $\mathrm{Tel} \cdot+38-099-568-05-79$ E-mail: iturdus@ukr.net

\section{Introduction}

Wetlands are known to be one of the most productive world ecosystems (Perennou et al., 2020). They provide plenty of ecosystem services including flood and erosion protection, water treatment, nutrient storage, conservation of biodiversity, food and fuel production, and carbon sequestration. The wetlands are also regarded as the most vulnerable habitats subjected to large-scale drainage, degradation and fragmentation and extremely sensitive to global climate change (Č́źžková et al., 2013; Reid et al., 2019). In forest ecosystems, insectivorous birds adapt more easily to such environmental changes (Bulakhov et al., 2015; Chaplygina et al., 2016, 2018; Chaplygina \& Pakhomov, 2020).

Many recent studies claim that artificial or restored wetlands may compensate for wetland loss and support waterbird conservation (Alexander et al., 2011; Ashoori, 2011; Sebastián-González et al., 2015; Keten et al., 2020). In cities, an essential part of these man-made landscapes is represented by sewage plants, well-equipped for pumping and treatment of wastewaters coming from the local population, utilities and industrial enterprises, where the water is disinfected at the final stages before discharging into reservoirs. The biodiversity of stable bird groups supported by these wastewater facilities in some parameters exceeds such of natural water bodies (Dranga et al., 2016; Fedun, 2017). These areas are valuable for the conservation of rare bird species such as the black-winged stilt (Himantopus himantopus L., 1758), a representative of the Recurvirostridae family included in the Red Data Book of Ukraine.

This is a large wader with contrasting plumage patterns, inhabiting wetlands of tropic, steppe, desert and semi-desert landscapes of Eurasia (Abdillah et al., 2012; Davis \& Hanson, 2014; Pierce \& Kirwan, 2020).

The breeding biology of the black-winged stilt is still poorly studied, although some surveys have been conducted in Italy (Valle \& Scarton, 2020), Spain (Arroyo, 2000; Cuervo, 2005, 2010), and Indonesia (Cross- land \& Sitorus, 2014). The highest number of these birds, about 10,000 nesting pairs have been recorded during the 1980-1990s in Spain and Turkey. The size of the breeding population in Doñana (south-west of Spain) widely varies, ranging from 50 pairs in dry years to more than 14,000 in wet years. Given that the total European population is estimated at $33,500-49,800$ pairs, up to $28-42 \%$ of European black-winged stilts reproduce in Doñana in some years (Figuerola, 2007; Toral \& Figuerola, 2012).

Nowadays, after a $30-50 \%$ decrease in the breeding numbers, the species has gained protected status in almost all southern countries (BirdLife, 2000). In Hungary, the species population increased from 20-25 nesting pairs in the 1980s to recently recorded 550-680 pairs (Pigniczki et al., 2019).

In Ukraine, black-winged stilts breed in Kherson and Mykolaiv regions (Chernichko \& Vinokurova, 2018; Moskalenko, 2018; Moskalenko \& Pliushch, 2018a, 2018b; Koshelev, 2020), Zaporizhzhia (Matrukhan, 2018), Dnipropetrovsk (Strigunov et al., 2003; Strigunov \& Potopa, 2011; Ponomarenko et al., 2018), Poltava (Gavris et al., 1993; Nadtochiy, 2018), Kharkiv (Banik \& Vergeles, 1993; Nadtochiy et al., 2001; Nadtochiy \& Osadchuk, 2013), Cherkasy (Gavriliuk \& Illyukha, 2013), Sumy (Knysh, 2001; Nadtochiy, 2018), Zhytomyr (Davydenko, 2001), Khmelnytskyi regions (Gulay \& Gulay, 1997).

The objective of the research was to study characteristics of the breeding biology of the black-winged stilt in muddy sites of the sewage plant in Kharkiv, Ukraine.

\section{Material and methods}

The census of breeding numbers of black-winged stilt was carried out in muddy sites of the wastewater treatment plant of Kharkiv (formerly known as Bezliudivski ponds) and at Novyi Liman Lake (4953'29" N 
$\left.36^{\circ} 15^{\prime} 21^{\prime \prime} \mathrm{E}\right)$ located in a former sandpit (Fig. 1a). The area sustains foraging, roosting and breeding waterbirds and other migratory bird species. Muddy sites are represented by fenced land areas where the sludge (sediments) is dried up. The main studies of the nesting biology of the wader were carried out in the spring - autumn of 2020-2021. Field surveys were conducted starting from the first ten days of March until late August 2021 in muddy sites of the wastewater treatment plant of Kharkiv (Bezliudivski ponds).

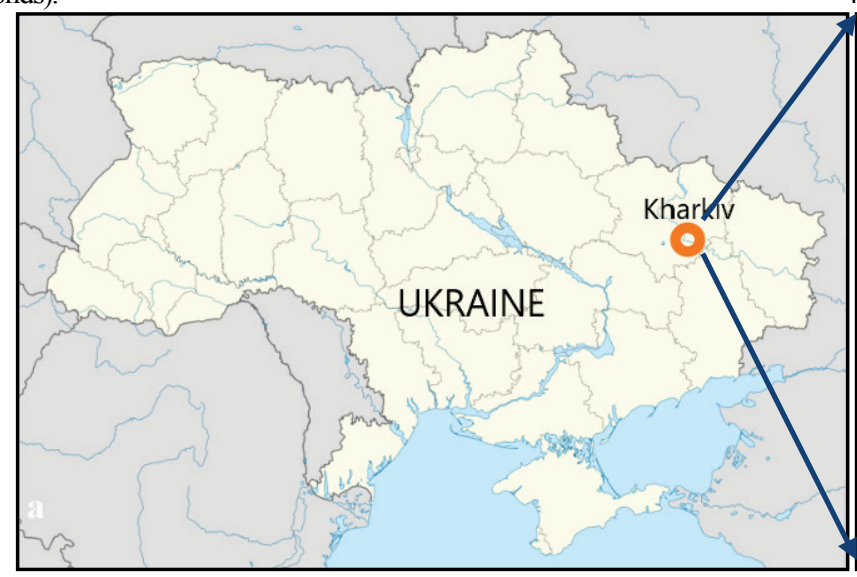

In 2020, black-winged stilts nested in four muddy areas, and in six in 2021. The black-winged stilt nesting sites are highlighted in colour: pink nesting in $2020\left(12-49^{\circ} 53 \prime 23^{\prime \prime} \mathrm{N} 36^{\circ} 16^{\prime} 41^{\prime \prime} \mathrm{E}\right.$; and $13-49^{\circ} 53^{\prime} 21^{\prime \prime} \mathrm{N}$ $36^{\circ} 16^{\prime} 38^{\prime \prime} \mathrm{E}$; $\left.18-49^{\circ} 53^{\prime} 16^{\prime \prime} \mathrm{N} 36^{\circ} 16^{\prime} 41^{\prime \prime} \mathrm{E}\right)$, red - 2021 (3-49 $53^{\prime} 45^{\prime \prime} \mathrm{N}$ $36^{\circ} 16^{\prime} 12^{\prime \prime}$ E, 11 - 49 $53^{\prime} 41^{\prime \prime} \mathrm{N} 36^{\circ} 16^{\prime} 01^{\prime \prime} \mathrm{E}, 31$ - 49 $53^{\prime} 46^{\prime \prime} \mathrm{N} 36^{\circ} 15^{\prime} 39^{\prime \prime} \mathrm{E}$,

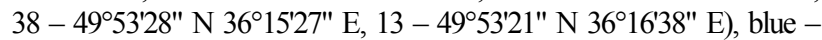
breeding sites in 2020 and 2021 (1 - 49 53'53" N 36 $166^{\circ} 03^{\prime \prime} \mathrm{E} ; 2$ 495' $49^{\prime \prime}$ N $36^{\circ} 16^{\prime} 07^{\prime \prime}$ E) (Fig. 1b).

Fig. 1. Layout of urban wastewater treatment plants in Kharkiv ( $a$ ) and nesting of stilts in silt areas in 2000-2021 is highlighted in blue (b), only in 2020 - in pink, only in 2021 - in red
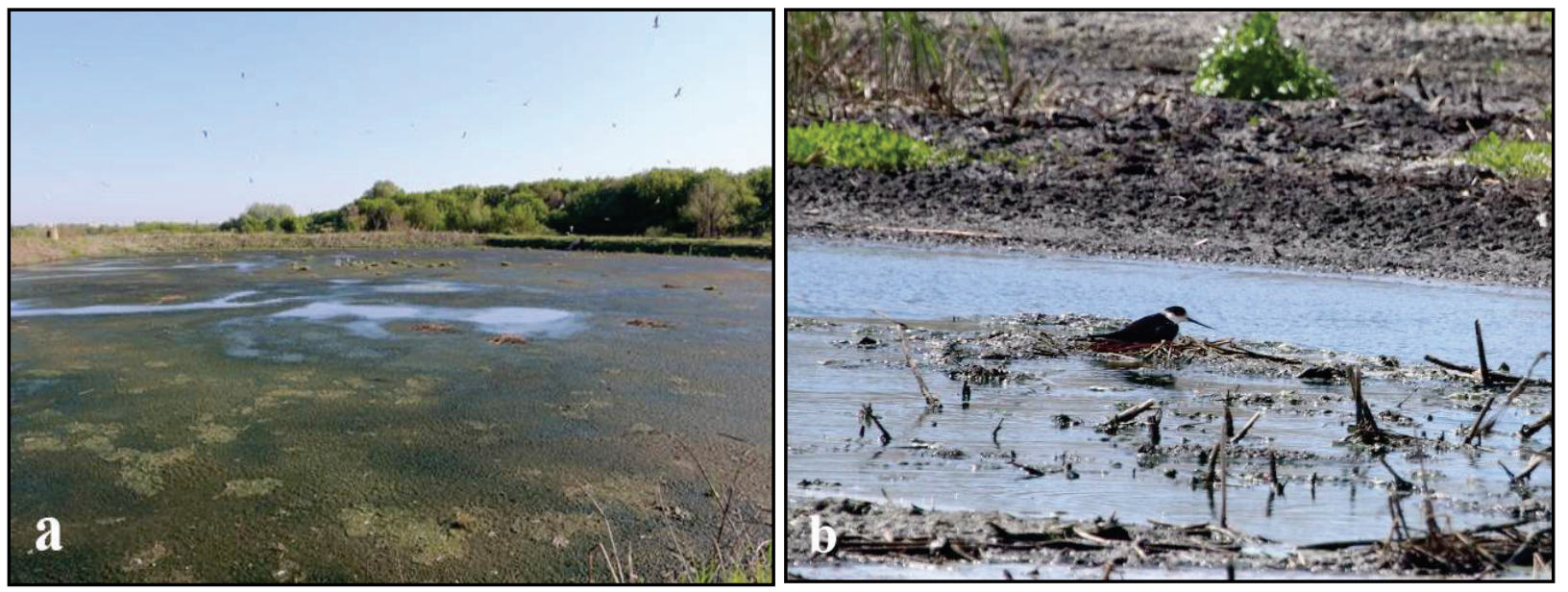

Fig. 2. Muddy sites of the wastewater treatment plant, Kharkiv $(a)$, the stilt incubates a clutch of eggs $(b)$

The final stages of water purification result in a mud layer in treatment facilities, which subsequently gets dehydrated in a natural way and turns into muddy areas (Fig. 2a). Within the treatment plant, these muddy sites have different water levels. Nesting waders prefer the sites with dried sediments resembling salt marsh shallows (Fig. 2b).

During rains, some areas are flooded with water and become muddy, which makes them difficult for stray animals that can feed on chicks, eggs and even adult birds. The advantage of building nests in such inaccessible places is that the incubating stilts are visible to predators due to their black and white coloration (Fig. 2b). Shallow areas warm up very quickly, which is a favourable basis for the development of various invertebrates the main food of stilts. Thus, during the year, these territories are attractive as feeding stations and resting places for various species of birds, in particular waders.

We described 21 nests of stilts at the sewage treatment plant of Kharkiv city. The nest locations were GPS-recorded and checked every 210 days during the incubation stage until the nesting success was detected. Each visit lasted no more than 5 minutes, and periods of extreme temperatures (dawn and noon) were avoided. We saw no predators benefiting from the disturbance caused to the nests by the researchers. The length and width of eggs were measured using a digital calliper with an accuracy of $0.01 \mathrm{~mm}$ and weighted using portable digital scales (accuracy $0.1 \mathrm{~g}$ ). The clutch was considered successful if at least one egg had hatched.
The hatching was confirmed if (1) a newly hatched nestling was found in the nest or nearby, (2) at least one egg showed signs of inevitable hatching (a cracked or perforated egg shell) or (3) the date when the egg disappeared coincided with that of expected hatching and no signs of predation were discovered. The nest was regarded as unsuccessful if(1) egg remains were found, (2) the nest was abandoned (cold eggs) or (3) the eggs disappeared before the expected hatching date.

The studies were carried out in compliance with the bioethics standards, in accordance with the regulation "European Convention for the Protection of Vertebrate Animals used for Experimental and other Scientific Purposes" (Strasbourg, 1986), violating no requirements of the "Convention on the Protection of Wild Flora and Fauna and Natural Environments habitat in Europe" (Berne Convention).

\section{Results}

In the territory of the Kharkiv wastewater treatment plant and the area around it, there is a colony of the black-headed gull Larus ridibundus (Linnaeus, 1766), one of the largest in Kharkiv Region. These birds make their nests on mud islets in open water areas and on reed-covered spots. According to staff-workers of the treatment plant, the gull colony has existed for over 25 years, and the number of birds varies annually and throughout the season. Various species of waders nest within the gull 
colony. The breeding of the stilt, a species from the Red Book of Ukraine, is unique for the city.

We recorded the first individuals of black-winged stilts Himantopus himantopus on 23.04.2020. The male was wading in shallow water in search of food within muddy site 2 of the sewage plant (49 $53^{\prime} 42^{\prime \prime} \mathrm{N}$ $36^{\circ} 16^{\prime} 11^{\prime \prime}$ E). A week later, on 01.05.2020 the stilts formed a pair in another mud site ( $49^{\circ} 53^{\prime} 49^{\prime \prime} \mathrm{N} 36^{\circ} 16^{\prime} 07^{\prime \prime}$ E). On 11.05.2020, seven birds were recorded in muddy site 2 . The first pair of black-winged stilts was incubating. The birds' behaviour allowed us to distinguish them easily from other individuals: the male flew from muddy site 2 to site 9 (49 $\left.533^{\prime} 50^{\prime \prime} \mathrm{N} 36^{\circ} 16^{\prime} 03^{\prime \prime} \mathrm{E}\right)$, located opposite, giving a loud call in flight. In the neighbouring site, the male feigned a broken wing and was leading us away from the nest.

In 2021, we recorded the first stilt individuals on their spring migration in the second decade of April (04.17.2021). Mass migration of birds was observed in the first ten days of May (10.05.2021 - 41 individuals).

In the surveyed areas, the stilts nest along the coastline, on small hummocks in shallow water, in separate plots of vegetation. Nests can be either fairly wet or located on dry mud banks next to a bush of plants (such as dandelion or dry sedge). Several nests were located in absolutely bare areas, completely covered with dry silt.

In 2020, we found 12 pairs of stilts in 4 silt fields. On the first silt site, 6 pairs were recorded, of which 5 nested. The sixth pair of birds moved to the second site for breeding.

Nest 1 was found at the first muddy site represented by depression with depths reaching up to 2.5 metres. The nest was composed of mud and lined with dry grass. It was located 7.5 metres from the wall and concealed by low reed thickets. The birds incubated 4 eggs, and in case of danger left the nest silently, walked 3-4 metres and only after that flew off. On 17.06.2020, we found 4 hatched chicks, all of which successfully left the breeding area.

In the same muddy site, there was nest 6 , the location of which differed from the other five nests. The clutch was placed directly on the surface of a mud sewage pond, almost without grass lining. The dam wall was about 6 metres away. When noticing us, this pair of birds always gave warning calls. On 12.07.2020, three chicks hatched in the nest.

Nest 2 looked like a mud elevation lined with dry grass, found on 08.06.2020 in the first muddy site. The birds incubated 3 eggs. A week later, the clutch was pecked.

On the first muddy site, the stilts built nest 3 (18.06.2020). A week later, the birds left the breeding area without laying eggs.

Nest 4 was found in the first muddy site and had a high cup. The nest was composed of mud, lined with dry grass and located 5.5 metres away from the wall. It was concealed by low reed thickets and other vegetation. On 12.07.2020, 2 eggs were found there. When seeing us, the pair of birds always gave warning calls. The construction and height of this nest were similar to nests 1 and 2, also found in the same muddy site. We associate this similarity with the fact that muddy site 1 was occasionally filled with water and the birds built the nest in such a way as to protect it from immediate ruination. The nest was abandoned, presumably due to the late start of breeding (12.07.2020). The birds of this pair were characterized by unusual wing patterns: they had a symmetrical notch, more pronounced in male compared with female.

On the second silt site with an area of $11,508 \mathrm{~m}^{2}, 4$ pairs of stilts nested.

Nest 1 was represented by a shallow depression in the ground with the abundant lining composed of dry grass. A stalk of reed was found nearby, concealing the clutch of four eggs (Fig. 3a). The bird was completely hidden from one side making it impossible to reveal the nest. The distance from the nest to the wall fencing the muddy site was about 4 metres. There was no grass in the adjacent area and the nest seemed to have been built on an islet. On 31.05, the nest contained 4 chicks. However, on 18.06 we found only 3 of them with the adults (Fig. 3b). One nestling had probably died.

Nest 2 was composed of mud and raised about $10 \mathrm{~cm}$ above the ground. It was lined with dry grass, including several leaves of pear tree and 5-7 small stalks resembling those of the reed. Two parents incubated in turns and frequently changed each other on the nest. On 28.05 , the nest contained a clutch of 4 unincubated fresh eggs (Fig. 4). Not far from the black-winged stilt's nest, $50 \mathrm{~cm}$ away, black-headed gulls Chroicocepha- lus ridibundus also nested. On 03.06.2020, the nest held 4 chicks, all of them successfully left the area on 13.08.2020.
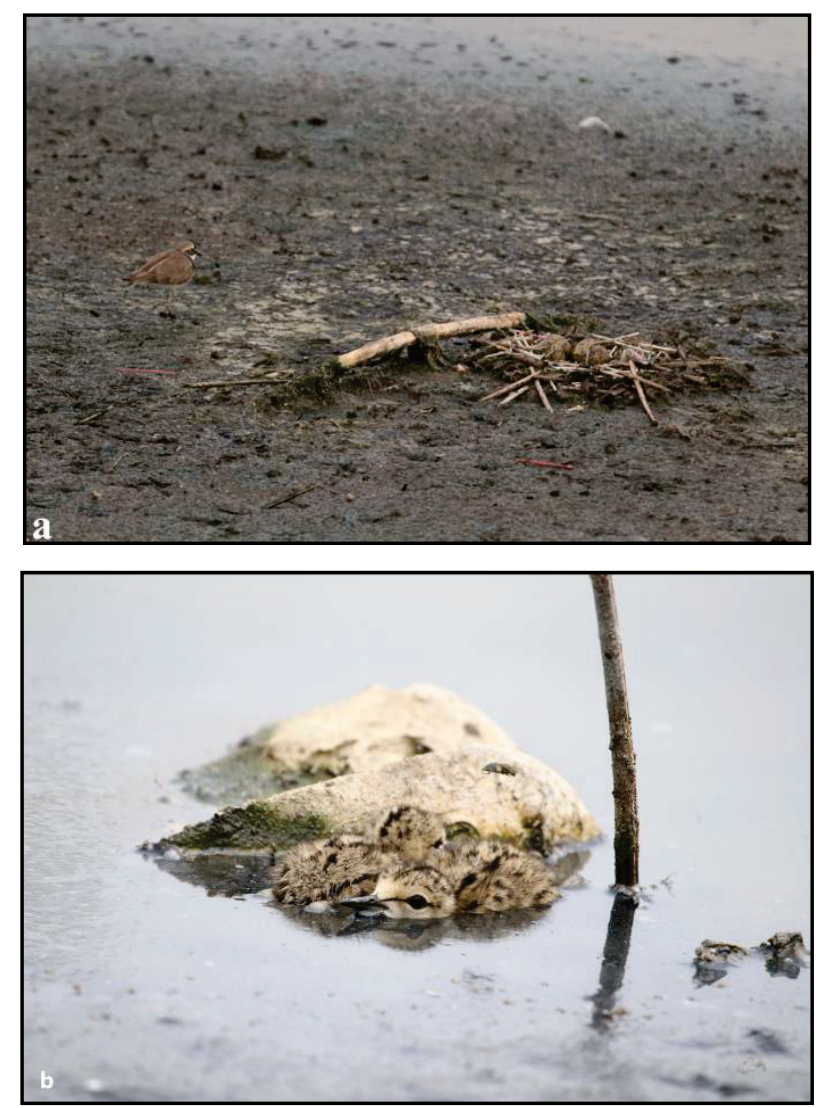

Fig. 3. Nest 1 of Himantopus himantopus on the second muddy site with the clutch $(a)$ and chicks in the breeding area $(b)$

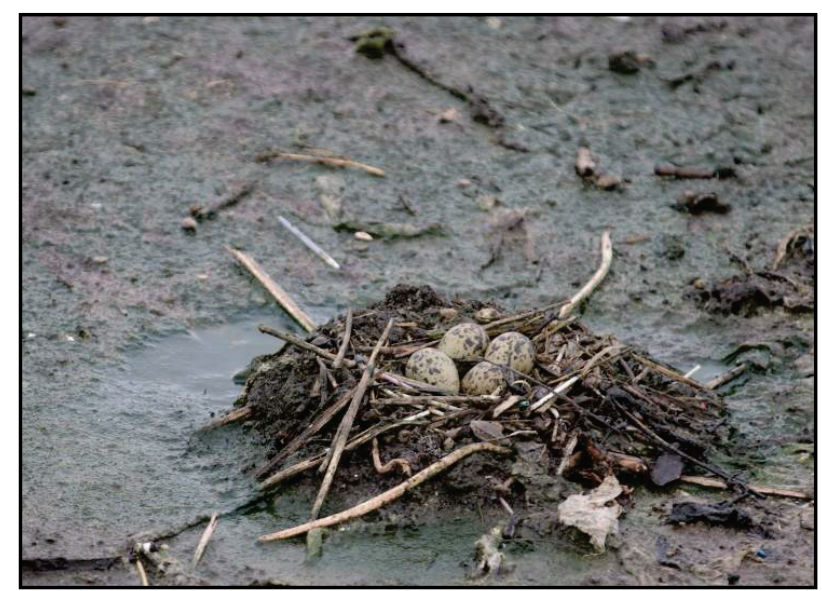

Fig 4. Nest 2 of Himantopus himantopus on the second muddy site

Nest 3 was composed of mud and lined with dry grass. Not far from the nest, there were found wild lettuce (Lactuca virosa) and giant sumpweed (Cyclachaena xanthiifolia (Nutt.) Fressen, a synonym to Iva xanthiifolia Nutt.). The distance from the nest to the wall fencing the muddy site was about 2.5 metres but the stilt's construction was well concealed by vegetation. On 31.05.2020, the nest contained 7 eggs of the following sizes: 42.5 x 31.3; 42.8 x 30.0; 41.6 × 31.0; 42.7 x 30.9; 42.9 × 31.3; 44.1 x $30.4 ; 43.1 \times 31.3 \mathrm{~mm}$. The incubation by one parent lasted $15-45 \mathrm{~min}$ $(\mathrm{n}=10)$. On average, every $23 \mathrm{~min}$ the birds took turns. The chicks hatched on 22.06.2020, five of them reached adult age and left the sewage plant on 13.08.2020.

Nest 4 resembled a small raft made of mud, erected several $\mathrm{cm}$ above the water. Reed thickets near the construction served as a good camouflage for the bird sitting in the nest located 3.5 metres away from the dam wall. After a week of incubation, all the eggs were pecked, more likely by 
gulls. Later this pair built a new nest on a muddy site 1 (17.07.2020) and laid 2 eggs. However, they abandoned the clutch in a week. Thus, muddy site 2 sheltered 4 pairs of black-winged stilts which built 4 nests in total. Not far from them, there were also found breeding black-headed gulls (74 nests on 31.05.2020) and 4 pairs of little ringed plovers (Charadrius dubius).

On the 12th silt site with an area of $4,159 \mathrm{~m}^{2}$, the nest was made of mud, lined with dry grass and well concealed by vegetation (Lactuca virosa). The distance from the nest to the wall around muddy site 12 was circa 5.5 meters. On 01.07.2020, there were four fresh eggs, the female was incubating and showing cautious behaviour. Approaching muddy site 12 , we startled black-winged stilts that took off with loud warning calls and did not allow us to get closer. They appeared extremely alarmed. Perhaps, their nest had been earlier destroyed, so they tried to protect their nest and chicks whenever they saw a living creature. On 17.07.2020, the nest was destroyed.

Muddy site 18 had 2 nests. In the first nest, on 03.06.2020, the female was incubating a clutch of 3 eggs. The nest was built in a depression and lined mainly with thin stalks. It was located 7.5 metres away from the dam, on a spot with no vegetation. The male and female showed signs of disturbance. Several days later, on 08.06.2020, the clutch was pecked out by the gulls nested in the neighbouring muddy site.

The same muddy site contained nest 2 with 3 eggs, located approximately 6 metres away from the previous pair of birds. The first egg was laid on 28.05. The nest was made of reed stalks. Plenty of dry sticks nearby, along with vegetation, provided good camouflage. The dam wall was at the distance of 8.5 metres. The pair was quite cautious, not allowing us to get closer with the male giving warning calls and flying over our heads. The clutch was destroyed, perhaps by gulls or other predators.

The muddy site of the wastewater treatment ponds of Kharkiv was the location for black-winged stilts until early August. Later, the birds started post-breeding movements. The last adults with juvenile birds were observed on 13.08.2020. According to the local staff-workers, in some years, stilts may remain until early October.

For the purpose of more effective protection, the nesting settlements of the black-winged stilt should be protected and the appearance of people in the nesting places should be prohibited. It is necessary to establish seasonal bird sanctuaries during the nesting period of waders.

In 2021, 19 pairs of stilts nested in seven muddy areas. The first stilt nest, built in thickets of reeds, was on site No. 1. Fifteen meters away from the nest towards the shore, there was a large 5 meter high cliff. A pair of birds nested in a small colony of black-headed gulls Chroicocephalus ridibundus (6 nests on 10.05.2021). For 3 weeks, there were 3-5 gulls (Larus cachinnans), which caused concern among the nesting species. Subsequently, the silt area was quickly overgrown with grass, which served as a proper concealment of the stilt chicks.

On site 2, six nests of stilt were found, located in a colony of the black-headed gull (L. ridibundus), the number of which as of 15.06.2021 was 387 adults. The first three nests were built among the first ones of the gulls in the stilt population. At the end of the first decade - beginning of the second decade of May, females incubated 3-4 eggs, hidden by a bush of dry grass. The site was quite wet, and because of that the egg clutches were slightly flooded with water from below. In shape and location, all nests were typical of a stilt and were very similar in structure and size to a tall plate. The distance between the first and second nest structures was about 6.5 meters, between the second and the third -4.5 meters. All chicks successfully hatched on June 5-6. In early August, half 5 chicks $(50 \%)$ - successfully left the nesting territory.

The other three nests were built later - during the second - third decade of May.

The first typical stilt nest in the form of a silt eminence with a bed of dry grass was located near a reed bush. On 16.05.2021, it contained a full clutch of 4 eggs, of which 4 chicks successfully hatched on 09.06.2021. Ultimately, only one chick survived. Rapid overgrowing of the site with vegetation improved its accessibility to land-based predators. In the third decade of July, adult birds with one flying chick moved to another site. The birds built the second nest from silt, which lifted it above the ground by $8-10$ centimeters. The litter was composed of dry grass, colourful reed- like tubules, and bright remnants of paper calendars. On 05.27.2021, the nest contained a clutch of three non-hatched fresh eggs. Sixty five centimeters away from the wader nest, black-headed gulls (Chroicocephalus ridibundus) nested. On 20.08.2021, all chicks successfully left the territory.

The next typical nest was well camouflaged by vegetation, built in the same place where stilts nested in 2020. Because of the behaviour of the birds, we assume that we observed the same pair over two years. Nest bedding was made of dry grass and coloured plastic debris. Egg sizes were: 41.8 x 38.0, 42.7 x 31.5, 41.5 x 31.8, 44.8 x 31.7. On 23.06.2021, the first 2 chicks and 2 eggs were recorded in the nest (Fig. 5). On 20.08.2021, all 4 chicks successfully left the territory.

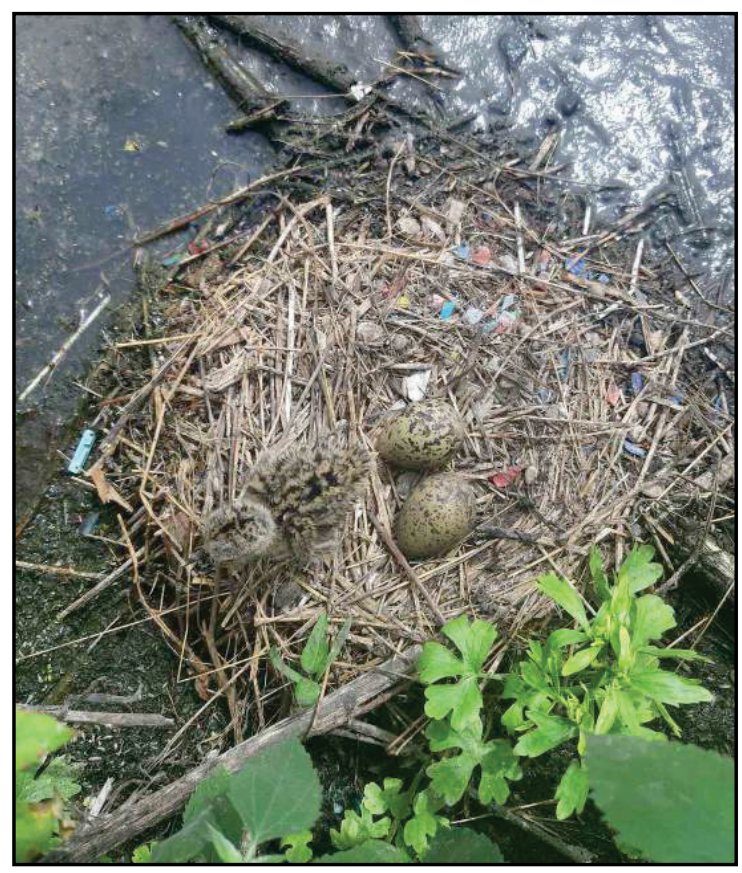

Fig. 5. Nest of Himantopus himantopus in the second muddy area interspersed with pieces of plastic

Thus, on the second silt site comprising the area of $11,508 \mathrm{~m}^{2}, 6$ pairs of stilts, as well as 274 pairs of black-headed gulls (Larus ridibundus), 2 pairs of little ringed plovers (Charadrius dubius) nested, and 9-16 individuals of ruff(Philomachus pugnax) fed.

On the third silt site, 3 pairs of stilts nested. Birds laid most of the eggs in 2021 in the second decade of May. In the first nest, in the form of a depression in the silt with a small amount of nesting material from dry stems of plants, there was a clutch of 4 eggs, which were periodically moistened with water. Eighty five percent of this area was filled with water.

The second nest differed in structure - the walls were made of dry vegetation, which raised the clutch above the water surface. This arrangement is uncommon for stilts. On 27.05, there was a clutch of 4 fresh eggs in the nest. Subsequently, the site was overgrown with grass, so it was not possible to trace the fate of the nest to the end (Fig. 6).

The third nest was supported by previous year's reed stems growing near the shore of silt site No. 3 (Fig. 7). There were 3 eggs in the nest found and measured. Egg sizes were: $45.9 \times 35.0,47.6 \times 31.9,45.9 \times$ 31.8. The birds were very careful. When someone appeared, they tried to lead the intruder away from the nest in various ways, the male often imitated a wounded bird: "falling to the ground with spread wings", "dragging the right wing along the ground". Sometimes the birds showed defensive postures - "bending the neck", in front of us on the camera. And this continued until we left the nesting territory. The aggressiveness of the demonstrative behaviour of stilts increased with the progression of the incubation period and reached its peak when the chicks hatched (in the third decade of June). On the 11th site on 06.23.2021, the last stilt nest with 2 eggs was found in the reproductive period of 2021, in a small colony of common tern (Sterna hirundo) (about 22-25 pairs), as well as one 
pair of little ringed plovers (Charadrius dubius (Scopoli, 1786)) and of lapwings (Vanellus vanellus). A pair of stilts settled there after the death of chicks in the previous nest. Unfortunately, this late clutch also perished.

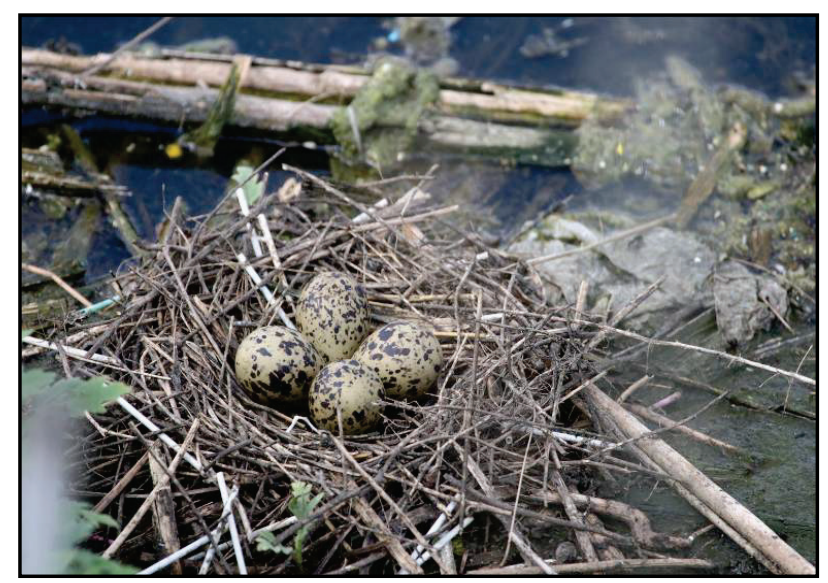

Fig. 6. A typical nest of Himantopus himantopus at the third silt site

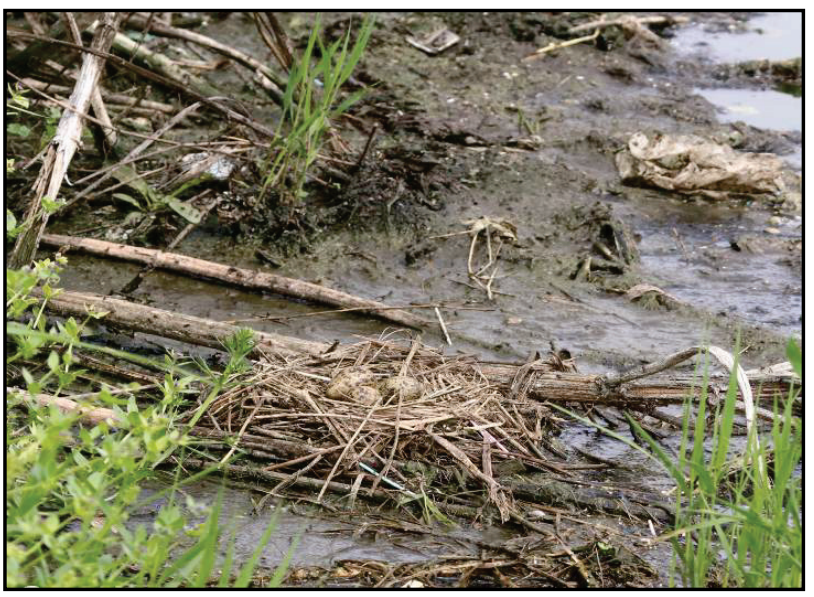

Fig. 7. Nest of Himantopus himantopus at the third muddy site (2021)

From the beginning of the spring season, 5-7 pairs of stilts occupied silt site 13 for a long time. For reproduction, most of the birds moved to other areas, where the population of the black-headed gull (Chroicocephalus ridibundus) was higher, which made it possible for other birds to successfully nest in its colonies and preserve their offspring through collective protection. Two stilt nests in this area were built like silt mounds with a tray lined with dry grass. Full clutches contained 4 eggs (13.06.2021 - the beginning of oviposition). The birds gave alarm calls when they saw a person walking by but did not react to the working equipment. Three chicks successfully flew from two nests (20.08.2021), which is $37.5 \%$.

Three pairs of stilts bred on 31 silt site. The first nest was found in the central part of this silt site, most of which was overgrown with grass by the middle of summer. On 10.05.2021, in a typical nest, there was a full clutch of 3 eggs, of which all chicks successfully hatched. At the age of 1520 days, the grown chicks were caught by predators (near the nesting area of waders, there is a burrow of foxes (Vulpes vulpes (Linnaeus, 1758)). Two more nests were built according to the "depression in silt" type, full clutches each having 3 to 4 eggs. Egg laying started on 23.05.2021 and 22.05.2021, respectively. The nesting area was quickly overgrown with vegetation, but the chicks survived, moving with adult birds to the neighboring territory.

For the second year in a row, a small black-headed gull colony (35 individuals with 9 nests as of 05.10.2021), 3 pairs of lapwings, 2 pairs of common redshank, and 2 pairs of little ringed plovers were located on the 38th silt site. Three typical stilt nests were found here; silt heights, covered from above with dry grass in the form of a tray. Constant water in the area formed small saucers between them. Two nests were located 15 meters offshore and two meters one from the other. The third nest was located 5.5 meters away from these two.

\section{Discussion}

Bird communities formed within wastewater treatment facilities of North-Western Ukraine are represented by 153 bird species (52.5\% species of all avifauna of the region), belonging to 40 families and 15 orders. Among them, 81 species are breeding (Fedun, 2017).

According to our preliminary data, the Kharkiv sewage plant supports 106 bird species. Of these, 46 species are nesting, 81 are only observed on migration, 6 are accidental visitors, and 10 species (including 1 nesting species) are rare and listed in the Red Data Book of Ukraine (Red Data Book, 2009) (Mamedova, 2020). Sedimentation pools of wastewater treatment plants have long been known as nesting grounds of blackwinged stilts (Rubenser, 1990; Stumberger \& Bracko, 1996; Nadtochiy et al., 2001). Twelve-fifteen pairs of this species in the studied area were first reported by Nadtochiy \& Osadchuk (2013).

In the nature, black-winged stilts make their nests among low vegetation or close to solitary-standing plants (Barati et al., 2001), sometimes in open areas of salt marshes, on sandy-shelly spits and islands (Koshelev \& Matrukhan, 2010; Koshelev, 2020). These birds frequently form mixedspecies colonies, including other species of the Charadriiformes order (Cuervo, 2010; Toral \& Figuerola, 2012). Being a plastic species, blackwinged stilts nest on banks, shores and islands of salt mounds amongst water of any salinity, occupy the spots overgrown with Salicornia sp. or other halophytes; use muddy shallows, swampy banks and shores (Bulakhov et al., 2008; Ashoori, 2011). The decrease in the stilt population in the study area with the start of rains is associated with the fact that the species prefer to live in shallow water between 6 and $21 \mathrm{~cm}$ deep. Changes in water levels also affect the number of waders and their feeding behaviour (Maheswaran et al., 2001)

The arrival of black-winged stilts to breeding grounds at the Kharkiv wastewater treatment plant was recorded in the second-third decade of April $(23.04 .2020 ; 17.04 .2021)$. Southward, in the northern part of the Azov Sea region, the birds usually appear at the beginning of April or even in late March (in years with early spring) (Koshelev et al., 2020). With stable water levels in a water body, the egg-laying starts when average daily temperatures reach about $15{ }^{\circ} \mathrm{C}$, mostly in April-May, not varying notably between years (Adamou et al., 2009).

Our research shows that the stilts start building nests and laying eggs immediately after their arrival at the nesting grounds. First eggs in the studied bird population were found on 01.05.2020 end 05.05.2021, seven days after the first birds had returned from the wintering grounds. The breeding periods significantly vary and are stretched out in time due to the weather and feeding conditions as well as predation pressure. The egglaying lasts until the first-second decade of July: 08.07.2020, 14.06.2021. Chicks hatch from late May (30.05.2020) throughout June to the first decade of July (02.07.2020). They were able to fly only a month later: 29.06.2020 (Fig. 8). In 2021, the first full clutches were recorded on May 7. The main peak of oviposition was observed in the second decade of May, and hatching of chicks was peaking throughout June. The last flying chicks were recorded on 20 August. Thus, the reproductive period in birds lasted 106 days. In 2020, it lasted 113 days from 23.04.2020 until 13.08.2020 (Fig. 9). The birds usually make nests on the ground. Their nest-building instincts are not well developed, resulting in primitive and often untidy constructions. The size and height vary depending on the type of plants and lining used for building.

Our studies have shown that typical nests for the species prevailed in the territory of the treatment plant - silt elevation with a grass tray. In just two years, $20(64.5 \% ; \mathrm{n}=31)$ such structures were recorded; in the silt pit - $10(32.3 \%)$, and one (3.2\%) was found in the form of an elevation of dry plant stems. The number of eggs in a nest ranged from 1 to 11 . "Double clutches" were common, i.e. laid by several females in the same nest (Kitagawa, 2005; Diallo et al., 2019). In the northern part of the Azov Sea region, the average clutch size of the black-winged stilt was $3.75 \pm$ $0.13(\mathrm{n}=13)$, with CV $=12.0 \%(\lim 3-4)($ Koshelev, 2020).

In the sewage plant, the average clutch size in the nests of $\mathrm{H}$. himantopus in 2020 was $3.8 \pm 0.09(\mathrm{n}=12, \lim 2-7)$, in the $2021-3.5 \pm 0.61$ $(\mathrm{n}=19, \lim 2-4)$. In the regions of Tokyo City around Tokyo Bay, this parameter amounted to $3.50 \pm 0.06(n=384, \lim 1-10)$. It has been suggested that the clutches with 3 or more eggs in the nest were laid by 2 or 3 
females. In monogamous pairs, the clutch size equaled $3.36 \pm 0.05(\mathrm{n}=$ 362, lim 1-4) (Kitagawa, 2005). In the Sahara Desert, Eastern Algeria these birds mostly have four-egg clutches (Adamou et al., 2009) with the last egg smaller than the others. The appearance of bigamous trios in clutches may be explained by the fact that some post-breeding groups that included a parent and a female offspring of the previous year or a family pair of birds and an unrelated female have not dissolved by the start of the next breeding season (Kitagawa, 2009).

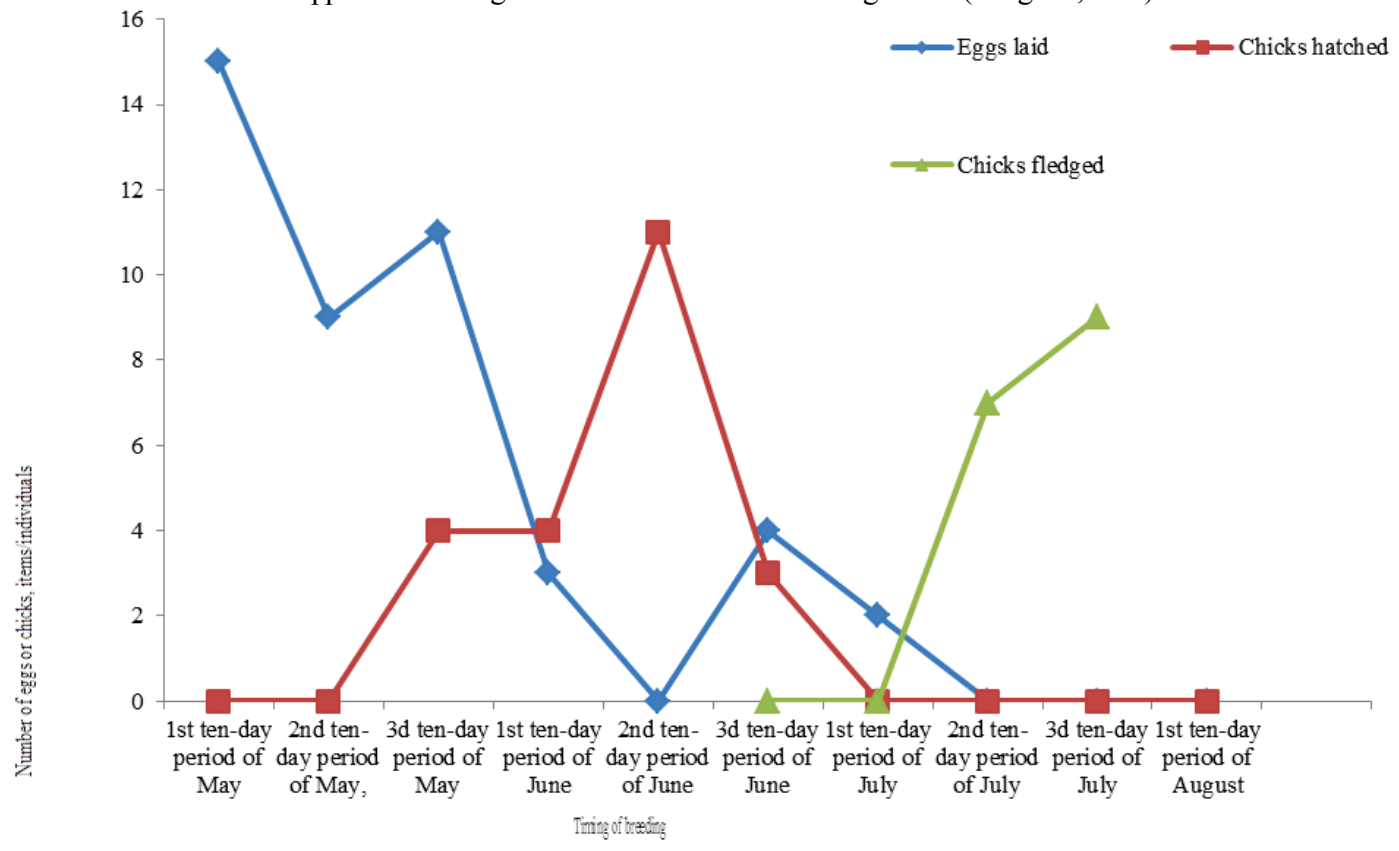

Fig. 8. Timing of the Himantopus himantopus breeding period at the Kharkiv sewage plant (2020)

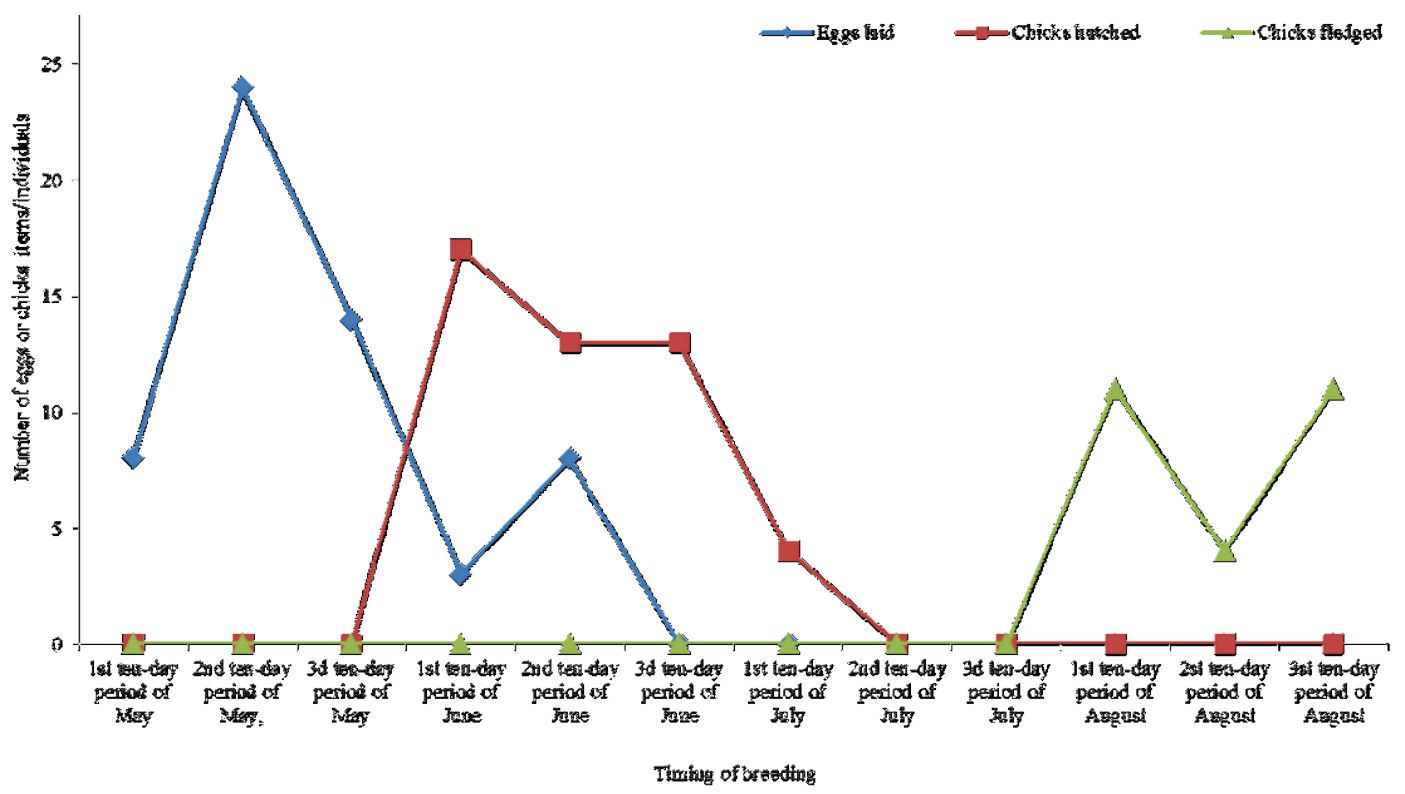

Fig. 9. Timing of the Himantopus himantopus breeding period at the Kharkiv sewage plant (2021)

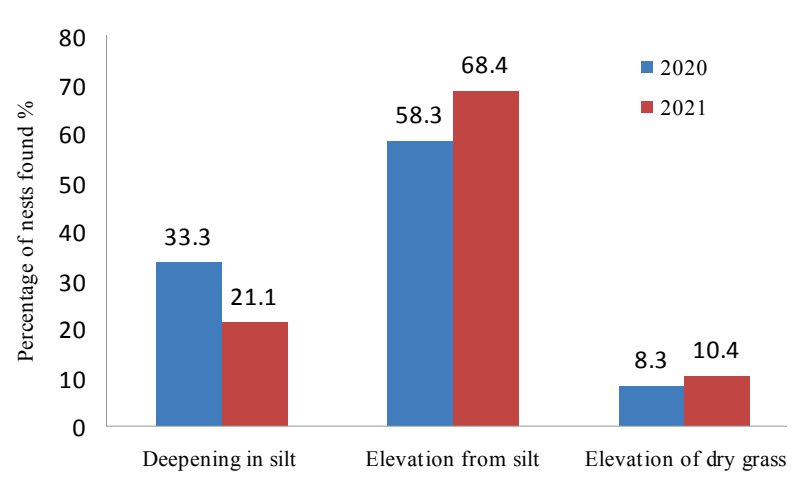

Fig. 10. Types of stilt nest locations

Average egg sizes and their limits in black-winged stilts are as follows: $42.8 \pm 0.7(41.6-44.1) \times 30.9 \pm 0.5(30.0-31.3) \mathrm{mm}$. The egg sphericity (Sph) is $72.2 \pm 2.0(68.9-74.5)$. Some literature data mention the deterioration of egg parameters due to the worsening hydrological conditions in wetlands (Adamou et al., 2009; Mytiai \& Matsyura, 2017).

The breeding success of black-winged stilts at the Kharkiv sewage plant is not high and reaches only $35.6 \%(\mathrm{n}=12)$. In 2021, a higher breeding success was seen $-38.8 \%(n=19)$. On average, $1.3 \pm 0.2$ and $1.4 \pm$ 0.01 fledgelings leave their nests. In Spain breeding success was $50 \%$ (Toral \& Figuerola, 2012).

\section{Conclusion}

Thus, the silt fields of water treatment plants in Kharkov are an important nesting place for black-winged stilts (Himantopus himantopus). 
In the muddy areas, the water level is different. The nesting stilts prefer areas of dry sediment, similar to shallows of salt marshes. The fate of 31 pairs has been traced. Breeding periods in birds vary considerably and stretch over time due to weather and feeding conditions, as well as pressure from predators. The egg laying process lasted from 01.05.2020, 07.05.2021 to the first ten days of July (08.07.2020). Chicks hatched from late May (30.05.2020) throughout June (10.06.2021) to the first decade of July (02.07.2020; 05.07.2021). The average clutch size in the nests of Himantopus himantopus in 2020 was $3.8 \pm 0.1(\mathrm{n}=12, \lim 2-7)$; and 3.5 $\pm 0.1(n=19, \lim 2-4)$ in 2021. Reproduction success of black-winged stilt in 2020 was $35.6 \%(n=12)$ and $38.8 \%(n=19)$ in 2021. In this territory, stilts stayed until the 3rd decade of August, after which the birds started migrating. The last individuals were recorded on 20.082021.

We express my gratitude to Victoria Luganskaya, a student of the H. S. Skovoroda Kharkiv National Pedagogical University for her support and participation in the study.

\section{References}

Abdillah, H., Iqbal, M., \& Amrul, H. M. (2012). First breeding records of blackwinged stilt in Indonesia. Stilt, 62, 18-21.

Adamou, A.-E., Kouidri, M., Chabi, Y., Skwarska, J., \& Bańbura, J. (2009). Egg size variation and breeding characteristics of the black-winged stilt Himantopus himantopus in a Saharan oasis. Acta Ornithologica, 44(1), 1-7.

Alexander, K., Sebastián-González, E., Botella, F., \& Sánchez-Zapata, J. (2011). Occupancy patterns of irrigation ponds by black-winged stilts Himantopus himantopus. Ardeola, 58(1), 175-182.

Arroyo, G. M. (2000). Influecia de las transformaciones humans de habitats costeros supralitorales sobre la ecologia de la reproduction de la ciguenuela Himantopus himantopus y la avoceta Recurvirostra avosetta en la Bahia de Cadiz: Aplicacion a la gestion de espacios naturals Protegidos. University of Cadiz, Puerto Real.

Ashoori, A. (2011). Breeding ecology of the black-winged stilt Himantopus himantopus in Boujagh National Park, Gilan Province, Northern Iran. Podoces, 6(1), $87-91$.

Banik, M. V., \& Vergeles, Y. I. (1993). Novaia nakhodka hnezdovoj kolonii khodulochnyka v Kharkovskoj oblasti [A new finding of a nesting colony of stilts in Kharkiv Region]. Berkut, 2, 55 (in Russian).

Barati, A., Etezadifar, F., \& Esfandabad, B. S. (2012). Nest-site selection and hatching success at a mixed-species colony of black-winged stilts Himantopus himantopus and gull-billed tern Gelochelidon nilotica. Avian Biology Research, $5(3), 142-146$.

BirdLife International (2000). Threatened birds of the world. Lynx Edicions and BirdLife International, Barcelona, Cambridge.

Bulakhov, V. L., Gubkin, A. A., Ponomarenko, O. L., \& Pakhomov, O. Y. (2008). Biologichne riznomanittya Ukrainy. Dnipropetrovska Oblast'. Ptahy: Negorobcepodibni (Aves: Non-Passeriformes) [Biological diversity of Ukraine. Dnipropetrovsk Region. Aves: Non-Passeriformes]. Dnipropetrovsk University Press, Dnipropetrovsk (in Ukrainian).

Bulakhov, V. L., Gubkin, A. A., Ponomarenko, O. L., \& Pakhomov, O. Y. (2015). Biologichne riznomanittya Ukrainy. Dnipropetrovska Oblast'. Ptahy: Gorobcepodibni (Aves: Passeriformes) [Biological Diversity of Ukraine. Dnipropetrovsk Region. Aves: Passeriformes]. Dnipropetrovsk University Press, Dnipropetrovsk (in Ukrainian).

Chaplygina, A. B., \& Pakhomov, O. Y. (2020). Trophic links of the blackbird (Turdus merula Linnaeus, 1758) in transformed forest ecosystems of North-Eastern Ukraine. Ekologia Bratislava, 39(4), 333-342.

Chaplygina, A. B., Savynska, N. O., \& Brygadyrenko, V. V. (2018). Trophic links of the spotted flycatcher, Muscicapa striata, in transformed forest ecosystems of North-Eastern Ukraine. Baltic Forestry, 24(2), 304-312.

Chaplygina, A. B., Yuzyk, D. I., \& Savynska, N. O. (2016). The robin, Erithacus rubecula (Passeriformes, Turdidae), as a component of autotrophic consortia of forest cenoses, Northeast Ukraine. Vestnik Zoologii, 50(4), 369-378.

Chemichko, J. I., \& Vinokurova, S. V. (2018). Nahodki vidov ptic, zanesennyh v Krasnuyu knigu, v bassejne reki Domuzla v mae $2017 \mathrm{~g}$. [Findings of red-listed bird species in the Domuzla river basin in May 2017]. Materials for the 4th edition of the Red Data Book of Ukraine. Animal Word. Series: Conservation Biology in Ukraine, 7(2), 353-355 (in Ukrainian).

Č́žzová, H., Květ, J., Comín, F. A., Pokorný J., \& Pithart, D. (2013). Aquatic sciences actual state of European wetlands and their possible future in the context of global climate change. Aquatic Sciences, 75, 3-26.

Crossland, A. C., \& Sitorus, A. W. (2014). Further records of black-winged stilt Himantopus (h.) himantopus in North Sumatra. Kukila, 18(1), 17-21.
Cuervo, J. J. (2005). Hatching success in avocet Recurvirostra avosetta and blackwinged stilt Himantopus himantopus. Bird Study, 52(2), 166-172.

Cuervo, J. J. (2010). Nest-site selection and characteristics in a mixed-species colony of avocets Recurvirostra avosetta and black-winged stilts Himantopus himantopus. Bird Study, 51(1), 20-24.

Davidenko, I. V. (2001). Gnezdovanie hodulochnika v Zhitomirskoj oblasti [Breeding of the stilt in Zhytomyr Region]. Vestnik Zoologii, 35(6), 70 (in Russian).

Davis, D. E., \& Hanson, C. H. (2014). Management of evaporation basins to reduce and avoid adverse impacts to waterbirds. Salinity and Drainage in San Joaquin Valley California, 5, 211-247.

Diallo, A. Y., Ndiaye, P. I., \& Ndiaye, S. (2019). Spatial distribution and nesting behavior of the black winged-stilt (Himantopus himantopus himantopus, Linnaeus 1758) in the urban wetland of Dakar Technopole (Senegal, West Africa). International Joumal of Biological and Chemical Sciences, 13(1), 3448.

Dranga, A. O., Gorlov, P. I., Matsyura, A., \& Budgey, R. (2016). Breeding biology of rook (Corvus frugilegus) in the human transformed steppe ecosystems (the case of Botievo Wind Farm). Biological Bulletin of Bogdan Chmelnitskiy Melitopol State Pedagogical University, 6(1), 41-62.

Fedun, O. M. (2017). Ornithocomplexes of territories of technological objects of the waste waters treatment of the north-eastern part of Ukraine [Bird communities of technological sites for the sewage treatment in North-Eastern Ukraine]. I. I. Schmalhauzen Institute of Zoology of NAS of Ukraine, Kyiv (in Ukrainian).

Figuerola, J. (2007). Climate and dispersal: Black-winged stilts disperse further in dry springs. PLoS One, 2(6), 539.

Gavrilyuk, M. N., \& Ilyukha, A. V. (2013). Gnezdovanie hodulochnika (Himantopus himantopus) i shiloklyuvki (Recurvirostra avosetta) v Cherkasskoj oblasti [Nesting of the stilt (Himantopus himantopus) and avocet (Recurvirostra avosetta) in Cherkasy Region]. Berkut, 22(2), 169-171 (in Russian).

Gavris, G. G., Slyusar, N. V., \& Sypko, A. V. (1993). Novye gnezdyashchiesya pticy Poltavskoj oblasti [New nesting birds of Poltava Region]. Vestnik Zoologii, 1, 88 (in Russian).

Gulay, O. V., \& Gulay, V. V. (1997). Hnizduvanyia dovhonoha u verkhiviakh Pivdennoho Buhu [Breeding of the stilt in the upper reaches of the Southern Bug]. Berkut, 6, 46 (in Ukrainian).

Keten, A., Sarcan, E., \& Anderson, J. T. (2020). Temporal patterns of wetlandassociated bird assemblages in altered wetlands in Turkey. Polish Journal of Ecology, 67(4), 316-330.

Kitagawa, T. (2005). The clutch size of the black-winged stilt Himantopus himantopus himantopus. Journal of the Yamashina Institute for Ornithology, 36(2), $117-119$.

Kitagawa, T. (2009). Bigamous trios in the black-winged stilt Himantopus himantopus himantopus: I. Pathways to form Bigamous Trios. Journal of the Yamashina Institute for Ornithology, 40(2), 73-82.

Knysh, N. P. (2001). Zametki o redkih i maloizuchennyh pticah lesostepnoj chasti Sumskoj oblasti [Notes on rare and poorly studied birds of the forest-steppe zone in Sumy Region]. Berkut, 10(1), 1-19 (in Russian).

Korzyukov, A. I. (2009). Kulik-dovgoníg (khodulichnik) [Black-winged Stilt Himantopus himantopus (Linnaeus, 1758)]. In: Akimov, I. A. (Ed.). Red Data Book of Ukraine. Animal World. Globalconsulting, Kyiv, 449 (in Ukrainian).

Koshelev, V. A., \& Matrukhan, T. I. (2010). Rozmishennya i struktura omitokompleksiv v agrolandshaftah pivdnya Zaporizkoyi oblasti [Distribution and structure of ornithological complexes in agricultural landscapes of the Zaporizhzhya Region]. Newsletter of the Zaporizka National University, 1, 39-52 (in Russian).

Koshelev, V. A., Pakhomov, O. Y., \& Busel, V. A. (2020). The formation of sclerophilic ornythocomplexes in the quarries in the South of Ukraine and their conservation prospects. Ecology, Environment and Conservation, 26(1), 411-419.

Koshelev, V. O. (2020). Ornitokompleksy yak elementy bioheotsenoziv pivdnia Ukrainy: Riznomanittia, struktura, okhorona [Bird communities as elements of biocenoses in the south of Ukraine: Development, structure, protection]. Oles Honchar Dnipro National University. Dnipro (in Ukrainian).

Maheswaran, G., \& Rahmani, A. R. (2001). Effects of water level changes and wading bird abundance on the foraging behaviour of black-necked storks Ephippiorhynchus asiaticus in Dudwa National Park, India. Journal of Biosciences, 26, 373-382.

Mitsch, W. J., Bernal, B., \& Hernandez, M. E. (2015). Ecosystem services of wetlands. International Journal of Biodiversity Science, Ecosystem Services Management, 11(1), 1-4.

Moskalenko, Y. O. (2018). Reiestratsiia ptakhiv, zanesenykh do Chervonoji knyhy Ukrainy na Oleshkivskykh piskakh, delty Dnipra ta Dniprovskij zatotsi protiahom 2006-2017 rokiv [Registration of birds listed in the Red Data Book of Ukraine in the Oleshkivski Sands, the Dnieper Delta and Dniprovskyi Bay during 2006-2017]. Conservation Biology in Ukraine, 7(2), 31-38 (in Ukrainian).

Moskalenko, Y. O., \& Pliushch, S. O. (2018a). Dani sposterezhen vydiv ptakhiv, zanesenykh do Chervonoji knyhy Ukrajiny, na terytorijakh Chomomorskoho Biosfernoho Zapovidnyka Natsionalnoji Akademiji Nauk Ukrajiny (20062017) [Observation data of bird species listed in the Red Book of Ukraine in arena areas of the Black Sea Biosphere Reserve of the National Academy of 
Sciences of Ukraine (2006-2017)]. Conservation Biology in Ukraine, 7(2), 39 48 (in Ukrainian).

Moskalenko, Y. O., \& Pliushch, S. O. (2018b). Dani sposterezhen vydiv ptakhiv, zanesenykh do Chervonoi knyhy Ukrajiny v pryberezhno-stepovykh rajonakh Chornomorskoho Biosfernoho Zapovidnyka protiahom 2008-2017 rokiv [Observation data of bird species listed in the Red Book of Ukraine in coastal-steppe areas of the Black Sea Biosphere Reserve during 2008-2017]. Conservation Biology in Ukraine, 7(2), 49-63 (in Ukrainian).

Mytiai, I. S., \& Matsyura, A. V. (2017). Geometrical standards in shapes of avian eggs. Ukrainian Journal of Ecology, 7(3), 264-282.

Nadtochiy, A. S., \& Osadchuk, V. V. (2013). Soobshchestvo ptic prudov-otstojnikov Bezlyudovskih ochistnyh sooruzhenij [The bird community of settling ponds of Bezliudivski wastewater treatment facilities]. In: Rusev I. T., Stoilovsky V. P., Korzyukov, A. I., \& Kivganov, D. A. (Eds.). Birds and Environment. Aprel, Odesa. Pp. 134-137 (in Russian).

Nadtochiy, A. S., Chernikov, V. F., \& Ruchkin, N. V. (2001). Soobshchestvo ptyts otstojnikov Orelkovskoho sakharnoho zavoda (Kharkovskaja oblast) [The bird community of settling ponds of the Orelkovsky Sugar Plant (Kharkiv Region)]. Proceedings of the Ukrainian Zoological Conference: Zoological Studies in Ukraine at the Border of Millenniums, Kryvyi Rih. Pp. 135-137 (in Russian).

Nadtochiy, G. S. (2018). Vstrechi redkih ptic v Harkovskoj, Sumskoj, Poltavskoj, Dnepropetrovskoj oblastyah v 2009-2017 gg. [Encounters of rare birds in Kharkiv, Sumy, Poltava, Dnipropetrosk regions during 2009-2017]. Conservation Biology in Ukraine, 7(2), $64-68$ (in Ukrainian).

Pierce, R. J., \& Kirwan, G. M. (2020). Black-winged stilt (Himantopus himantopus), version 1.0. In: Billerman, S. M., Keeney, B. K., Rodewald, P. G., \& Schulenberg, T. S. (Eds.). Birds of the World. Cornell Lab of Ornithology, Ithaca.
Pigniczki, C., Nagy, T., Oláh, J., Nagy, G. G., Karcza, Z., \& Schmidt, A. (2019). Breeding, dispersal, migration and conservation of the black-winged stilt (Himantopus himantopus) in Hungary. Ornis Hungarica, 27(2), 13

Ponomarenko, O. L., Banik, M. V., \& Barabash, R. I. (2018). Dannye nablyudenij za vidami ptic, zanesennyh v Krasnuyu knigu Ukrainy, v period 2009-2017 gg. v Dnepropetrovskoj oblasti [Observation data of bird species listed in the Red Book of Ukraine during the period 2009-2017 in Dnipropetrovsk Region]. Conservation Biology in Ukraine, 7(2), 177-183 (in Ukrainian).

Reid, A. J., Carlson, A. K., Creed, I. F., Eliason, E. J., Gell, P. A., Johnson, P. T. J. Kidd, K. A., MacCormack, T. J., Olden, J. D., Ormerod, S. J., Smol1, J. P., Taylor, W. W., Tockner, K., Vermaire, J. C., Dudgeon, D., \& Cooke, S. J. (2019). Emerging threats and persistent conservation challenges for freshwater biodiversity. Biological Reviews, 94, 849-873.

Rubenser, H. (1990). Erstbrutnachweis des Stelzenläufers (Himantopus himantopus) für Oberösterreich auf der Kläranlage Asten/Linz. Öko-L. 12, 27-32.

Sebastián-González, E., \& Green Andy, J. (2015). Reduction of avian diversity in created versus natural and restored wetlands. Ecography, 39(12), 1736.

Stumberger, B., \& Bracko, F. (1996). Gnezditev polojnika (Himantopus himantopus) vormoskin bazenih za odpadne vode. Acrocephalus, 17(78-79), 135-143.

Toral, G. M., \& Figuerola, J. (2012). Nest success of black-winged stilt Himantopus himantopus and kentish plover Charadrius alexandrinus in rice fields, Southwest Spain. Ardea, 100(1), 29-36.

Valle, R. G., \& Scarton, F. (2020). Feasibility of counting breeding pied avocets and black-winged stilts using drones. Wader Study Group Bulletin, 120(3), 1-9. 